\title{
No long-term complications after pulmonary embolism in an infant with multiple risk factors
}

\author{
Michalina Kołodziejczak', Michał Kołodziejczak² \\ 'Department of Anesthesiology and Intensive Care, Collegium Medicum Bydgoszcz, Nicolaus Copernicus University Torun, \\ Antoni Jurasz University Hospital No.1, Bydgoszcz, Poland \\ 2Department of Paediatrics and Cardiology with Division of Newborn Pathology, The Josef Brudzinski Provincial Children's \\ Hospital in Bydgoszcz, Poland
}

\section{ABSTRACT}

Pulmonary embolism (PE) in the paediatric population is rare and is characterised by unspecific presentation, misdiagnosis, and high mortality rates. An unusual case of pulmonary embolism in an infant with lower extremity plaster splints due to congenital clubfoot is presented. A male infant, 1.5 months old, was hospitalized due to otitis and suspicion of congenital heart disease. Generalized cyanosis with simultaneous saturation drops occurred only during physical effort. The clinical presentation represented the features of PE in the course of lower limb thrombosis, which were confirmed by laboratory tests and chest angio-CT. The diagnosis was amended, and heparin was administered, which resulted in a gradual, systematic improvement of the clinical condition. In a follow-up diagnosis, gene mutation of factor V Leiden was found. During 13 years of follow-up no recurrent thrombotic events were observed.

KEY WORDS:

pulmonary embolism, infant, V Leiden.

\section{INTRODUCTION}

Pulmonary embolism (PE) in the paediatric population is rare, with the National Hospital Discharge Survey reporting the incidence of clinically important childhood PE as $0.9 / 100000$ children per year, based on 23 years of admission and autopsy data [1]. Prompt recognition and treatment of $\mathrm{PE}$ is crucial, considering the consequences of misdiagnosis or delay of therapy [2]. The presentation of PE is nonspecific, and presenting concerns often overlap with other conditions, especially in infants or critically ill children, leading to a pronounced underrecognition and delays in diagnosis [3]. Commonly predisposing risk factors for $\mathrm{PE}$ in children can be patient-specific (obesity, inflammatory conditions, malignancy, congenital heart disease) or intervention-specific (post procedural immobility, central venous catheter placement, recent surgery, or trauma) $[1,2]$.

\section{PATIENT INFORMATION AND CLINICAL FINDINGS}

A male infant, 1.5 months old, was hospitalized in the district hospital due to otitis (Table 1). The child was from a second pregnancy that ended with premature delivery ( $36 \mathrm{Hbd}$ ), with 9 points in Apgar score and a birth body weight of $3440 \mathrm{~g}$. From the $14^{\text {th }}$ day of life, he was treated with lower extremity plaster splints due to congenital clubfoot. Due to decreases in saturation and concomitant cyanosis, the child was referred to the Provincial Children's Hospital for a suspected congenital heart defect. During sleep, the child's skin was pink, with a slight cyanosis of the mucous membranes, saturation was $88 \%$ without oxygen administration. When the child was crying or being fed, a generalized skin cyanosis on the face, chest, and upper limbs was present, with simultaneous decrease of saturation to $73 \%$; when oxygen was

\section{ADDRESS FOR CORRESPONDENCE:}

Michalina Kołodziejczak, Department of Anaesthesiology and Intensive Care, Antoni Jurasz University

Hospital No. 1 in Bydgoszcz, Marii Curie-Skłodowskiej 9, 85-094 Bydgoszcz, Poland,

e-mail: kolodziejczak.michalina@gmail.com 
TABLE 1. Timeline

\begin{tabular}{|c|c|}
\hline Date & Event/procedure \\
\hline 25.01.2008 & Birth \\
\hline 07.02 .2008 & Application of the first dressings on clubfoot \\
\hline 12.02 .2008 & Application of the second dressings on clubfoot \\
\hline 19.02.2008 & Application of the third dressings on clubfoot \\
\hline 27.02.2008 & Application of the fourth dressings on clubfoot. Referral to hospital for 07.03 .2008 for tenotomy \\
\hline 04.03.2008 & Admission to in district hospital due to otitis \\
\hline 11.03.2008 & $\begin{array}{l}\text { Transfer to the provincial children's hospital. Admission to the Department of Paediatrics and Cardiology with Division } \\
\text { of Newborn Pathology }\end{array}$ \\
\hline 13.03.2008 & Chest X-ray ap. Lung fields without focal changes \\
\hline 14.03.2008 & Pneumological consultation \\
\hline 15.03.2008 & Admission to the ICU due to suspicion of PE \\
\hline 18.03.2008 & $\begin{array}{l}\text { Chest } \mathrm{X} \text {-ray ap. Parenchymal thickening on the right side of pulmonary hilus -inflammatory? (peripheral location is charac- } \\
\text { teristic for embolism). Rich vascular drawing of cavities }\end{array}$ \\
\hline 25.03.2008 & $\begin{array}{l}\text { Chest angio-CT. Changes at the level of the lobar arteries that may correspond to embolic material. Consolidation } \\
\text { of the pulmonary parenchyma visible on both sides of the dorsal part of the lungs }\end{array}$ \\
\hline 01.04 .2008 & Discharge from the ICU \\
\hline \multirow[t]{2}{*}{ 02.04.2008 } & Echocardiography. Trace patency of the foramen ovale of the atrial septum \\
\hline & Chest X-ray ap. In the upper right pulmonary field - foggy shadow \\
\hline 08.04.2008 & Chest X-ray ap. Complete regression of previously described changes \\
\hline 09.04.2008 & Discharge from the Hospital \\
\hline 22.04.2008 & Orthopaedic control. Contraindications to the use of plaster splints, recurrence of deformities \\
\hline 06.05.2008 & Chest angio-CT. Features of PE have not been demonstrated \\
\hline 02.07 .2008 & Termination of heparin treatment, recommendation for anticoagulation in the perioperative period of clubfoot surgery \\
\hline 02.10 .2008 & $\begin{array}{l}\text { Result of haematological diagnostics. } \\
\text { APTT } 34 \mathrm{~s} \text { (norm to } 40 \mathrm{~s} \text { ), INR } 1.05 \text { (norm to } 1.25 \text { ), fibrinogen } 2.69 \mathrm{~g} / \mathrm{l} \text {, antithrombin III } 120.29 \% \text {, D-dimer }<0.5 \mu \mathrm{g} / \mathrm{ml} \text {, } \\
\text { ( protein } 81.11 \% \text {, free S protein antigen (Elisa method) - } 110 \% \text {, gene mutation of factor V Leiden - positive (heterozygote), } \\
\text { mutation of the prothrombin gene G20210A - absent (G/G genotype) }\end{array}$ \\
\hline
\end{tabular}

additionally administered $(6 \mathrm{l} / \mathrm{min}$ flow on the oxygen mask) the saturation increased to $93 \%$. Physical examination revealed a sore throat and sharp symmetrical vesicular sound and single rales by lung auscultation. The heart rate was regular at $100 / \mathrm{min}$, and heart tones were of appropriate volume and accentuation. Bilateral lower extremity plaster splints were present.

\section{DIAGNOSTIC ASSESSMENT AND THERAPEUTIC INTERVENTION}

Anti-inflammatory treatment was initiated due to a suspicion of respiratory infection onset. During hospitalization, the child's condition worsened, cough and auscultatory alternans over the lungs intensified, and oxygen saturation dropped to $70 \%$. When the plaster splints were removed for the medical examination, cyanosis of lower extremities was revealed. In control laboratory tests, D-dimers were $>3.0 \mu \mathrm{g} / \mathrm{ml}$ significantly exceeding the norm of $<0.5 \mu \mathrm{g} / \mathrm{ml}$ and an undetectable level of fibrinogen were found (Table 2).
Suspecting the features of PE in the course of lower limb thrombosis, due to lower extremity plaster splint immobilization, the child was transferred to the intensive care unit (ICU) on the $4^{\text {th }}$ day of stay, and unfractionated heparin (loading dose of 400 IU, followed by continuous flow of $150 \mathrm{IU} / 3 \mathrm{ml} / \mathrm{h}$ under the monitoring of coagulation profile) was immediately included in the treatment, which resulted in a gradual, systematic improvement of clinical condition. In computed tomography angiography of the pulmonary vessels features of PE were identified. After 17 days of ICU stay, the child was transferred to the cardiology department to continue medical treatment, and unfractionated heparin was switched to low-molecular-weight heparin (LMWH, $2 \times 2.5 \mathrm{mg}$ ). Oxygen saturation (98-100\% without additional oxygen administration), coagulation indicators, as well as control chest X-ray were within the normal limits. The child was discharged home on day 30 of hospitalization. Dose reduction of LMWH to a prophylactic dose was recommended 2 weeks after discharge $(1 \times 3 \mathrm{mg})$. 
TABLE 2. Laboratory parameters for the day of PE diagnosis

\begin{tabular}{|c|c|c|}
\hline Laboratory test & Value & Laboratory norm \\
\hline \multicolumn{3}{|l|}{ Haematology } \\
\hline APTT & $26.9 \mathrm{~s}$ & $25-43 s$ \\
\hline D-dimer & $>3.0 \mu \mathrm{g} / \mathrm{ml}$ & $<0.5 \mu \mathrm{g} / \mathrm{ml}$ \\
\hline fibrinogen & undetectable & $150-350 \mathrm{mg} / \mathrm{ml}$ \\
\hline PT & $12.6 \mathrm{~s}$ & $12-16 s$ \\
\hline prothrombin ratio & $103.6 \%$ & $80-120 \%$ \\
\hline \multicolumn{3}{|l|}{ Biochemistry } \\
\hline CRP & $0.2 \mathrm{mg} / \mathrm{dl}$ & $0-5 \mathrm{mg} / \mathrm{dl}$ \\
\hline PCT & $<0.5 \mathrm{ng} / \mathrm{ml}$ & $<0.5 \mathrm{ng} / \mathrm{ml}$ \\
\hline Blood glucose & $110 \mathrm{mg} / \mathrm{dl}$ & $75-106 \mathrm{mg} / \mathrm{dl}$ \\
\hline $\mathrm{Cl}^{-}$ & $99 \mathrm{mmol} / \mathrm{l}$ & $98-107 \mathrm{mmol} / \mathrm{l}$ \\
\hline $\mathrm{Mg}^{2+}$ & $1.09 \mathrm{mmol} / \mathrm{l}$ & $0.73-1.1 \mathrm{mmol} / \mathrm{l}$ \\
\hline $\mathrm{K}^{+}$ & $5.3 \mathrm{mmol} / \mathrm{l}$ & $3.5-5.5 \mathrm{mmol} / \mathrm{l}$ \\
\hline $\mathrm{Na}^{+}$ & $136 \mathrm{mmol} / \mathrm{l}$ & $130-150 \mathrm{mmol} / \mathrm{l}$ \\
\hline $\mathrm{Ca}^{2+}$ & $9.7 \mathrm{mg} / \mathrm{dl}$ & $8.8-10.8 \mathrm{mg} / \mathrm{dl}$ \\
\hline \multicolumn{3}{|l|}{ Arterial blood gases } \\
\hline $\mathrm{pH}$ & 7.385 & $7.35-7.45$ \\
\hline $\mathrm{pCO}_{2}$ & $39.8 \mathrm{~mm} \mathrm{Hg}$ & $35-45 \mathrm{~mm} \mathrm{Hg}$ \\
\hline $\mathrm{pO}_{2}$ & $52.4 \mathrm{~mm} \mathrm{Hg}$ & $80-100 \mathrm{~mm} \mathrm{Hg}$ \\
\hline $\mathrm{HCO}_{3}^{-}$ & $23.3 \mathrm{mmol} / \mathrm{l}$ & $21-25 \mathrm{mmol} / \mathrm{l}$ \\
\hline $\mathrm{BE}$ & $-1.8 \mathrm{mmol} / \mathrm{l}$ & \\
\hline satO $_{2}$ & $86.7 \%$ & \\
\hline
\end{tabular}

\section{FOLLOW-UP AND OUTCOMES}

Further coagulation system laboratory parameters showed a reduced level of $S$ protein. Molecular analysis showed gene mutation of factor V Leiden (heterozygote), while the level of free $S$ protein antigen (Elisa method) was $110 \%$ and mutation of the prothrombin gene G20210A was absent (G/G genotype).

Full lower-extremity plaster casts were applied between the $7^{\text {th }}$ and $12^{\text {th }}$ month of life, which were changed to lower extremity plaster splints between the $12^{\text {th }}$ and $18^{\text {th }}$ month of life. During those months the child received the prophylactic dose of LMWH. Ultimately, no surgical intervention was needed. Treatment with LMWH was terminated once the orthopaedic management was completed. The patient is currently 13 years without recurrent thrombotic events, does not require any antithrombotic medications, and is otherwise healthy.

\section{DISCUSSION}

Diagnostic tools for PE in neonates and infants are sparse, which, together with the rare occurrence of $\mathrm{PE}$ in the paediatric population, makes quick identification and treatment of the disorder a challenge [4]. Pre-born newborns are particularly predisposed to thrombosis development due to frequent infections and immaturity of coagulation system or its disorders. The newborn's haemostatic system matures and reaches adult values after about 6 months [5]. Up to that point, plasma concentrations of procoagulants, anticoagulants, and proteins involved in fibrinolysis can be significantly reduced as compared to adult values [6]. Congenital forms of thrombophilia (including: a resistance to activated protein C, deficiency of coagulation inhibitors - antithrombin III, protein $\mathrm{C}$, protein $\mathrm{S}$, the presence of elevated concentration of factor VIII, dysfibrinogenaemia, dysplasminogenaemia, and mutation of prothrombin gene 20210A can also appear in the first months of life, adding on to an increased thromboembolic risk in this population. The most common defect, constituting as much as $46 \%$ of all congenital thrombophilia and present in the reported case, is a resistance to activated protein $\mathrm{C}$ due to the gene point mutation of factor $\mathrm{V}$ Leiden, which becomes resistant and not degraded [7]

In the presented case, the infant had a number of risk factors for thrombosis development: he was born prematurely with an immature coagulation system, had 
immobilization of lower extremities, was admitted with infection, and had underlying, undiagnosed congenital thrombophilia. Through thorough medical examination, appropriate laboratory tests, and quick diagnosis followed by targeted therapy the patient reached full recovery. The most alarming symptom during the initial clinical presentation was generalized cyanosis occurring only during physical effort, with simultaneous saturation drops, that could equally have been associated with undiagnosed congenital heart disease, which was not present in this patient. The correct differential diagnosis prevented a potentially fatal course of PE and asserted for lack of thrombotic events over the course of 13 years of follow-up. Thus, awareness about the vague clinical presentation of $\mathrm{PE}$ in the paediatric population plays a detrimental role in lowering the mortality risk of neonates and infants.

\section{DISCLOSURE}

The authors declare no conflict of interest.

\section{REFERENCES}

1. Stein PD, Kayali F, Olson RE. Incidence of venous thromboembolism in infants and children: data from the National Hospital Discharge Survey. J Pediatr 2004; 145: 563-565.

2. Pelland-Marcotte MC, Tucker C, Klaassen A, et al. Outcomes and risk factors of massive and submassive pulmonary embolism in children: a retrospective cohort study. Lancet Haematol 2019; 6: e144-e153.

3. Andrew M, Mongale PT, Brooker L. Thromboembolic complications during infancy and childhood, BC Decker Inc, Hamilton, Ontario 2000.

4. Paes BA, Nagel K, Sunak I, et al. Neonatal and infant pulmonary thromboembolism: a literature review. Blood Coagul Fibrinolysis 2012; 23: 653-662.

5. Andrew M, Paes B, Milner R, et al. Development of the human coagulation system in the full-term infant. Blood 1987; 70: 165-172.

6. Williams MD, Chalmers EA, Gibson BE. The investigation and management of neonatal haemostasis and thrombosis. Br J Haematol 2002; 119: 295-309.

7. Svensson PJ, Dahlback B. Resistance to activated protein C as a basis for venous thrombosis. N Engl J Med 1994; 330: 517-522. 

